\title{
Eye and Hand on Shakespeare's Stage
}

\author{
JOHN H. ASTINGTON
}

Towards the end of Twelfth Night, Feste delivers to Olivia a letter from her steward Malvolio, who has been locked up to cure his supposed fit of insanity. Asked to read it out, he proceeds as follows:

Look then to be well edified when the fool delivers the madman. (Reads madly) 'By the lord, madam' -

Oli. How now, art thou mad?

Clo. No, madam, I do but read madness. And your ladyship will have it as it ought to be, you must allow vox.

$$
(\text { V.i.290-6) })^{1}
$$

By affecting an absurdly demented voice for the words of the letter, Feste is practising, in his own way, one of the arts of the Elizabethan actor. If those apprentices to the trade, the boy actors who took women's roles, were taught in any formal way by their masters, rather than simply having picked things up by intelligent emulation, they learnt the three v's, 'called vox, vultus, vita, voice, countenance, life,' as Thomas Wright translates them in his book The Passions of the Minde, first published in $1601 .^{2}$ Native English nomenclature reduced them to the two a's, which Boyet overhears Navarre and his courtiers drilling into the page Moth in preparation for the masque of Muscovites in Love's Labours Lost:

Action and accent did they teach him there:

'Thus must thou speak,' and 'thus thy body bear.'

(V.ii.99-100)

The word 'action,' commonly used to refer to the physical expressiveness of the actor as it was apprehended visually, covered not only the stance and gait, the posture and movement of the limbs, trunk, and head, but also the crucially important language of the face, 'vultus,' as these lines from Shakespeare's King John make clear: 
... he that speaks doth gripe the hearer's wrist, Whilst he that hears makes fearful action

With wrinkled brows, with nods, with rolling eyes.

(IV.ii.190-2)

It is with these visual languages, the arts of action, of vultus and vita, with which I am concerned here, but it is as well to insist that they were understood as parts of a whole, expressive and concrete, the function of which might be variously expressed as holding the mirror up to nature or as showing, and hence engaging, the mind, the heart, and the soul:

the affection poureth forth itselfe by all meanes possible, to discouer vnto the present beholders and auditors, how the actor is affected, and what affection such a case and cause requireth in them: by mouth he telleth his mind; in countenance he speaketh with a silent voice to the eyes; with all the vniuersall life and bodie he seemeth to say, Thus we moue, because by the passion thus we are mooued, and as it hath wrought in vs so it ought to worke in you. ${ }^{3}$

Elizabethan actors bodied forth the common notion, and the unchanging currency of acting, that thought and desires revealed themselves in gesture, movement, and facial expression. Only by a special understanding with the audience, arrived at by a clear declaration of what he was about, was the comic deceiver or villain allowed to break the assumed correspondence between external appearance and internal feeling:

For when my outward action doth demonstrate

The native act and figure of my heart

In complement extern, tis not long after

But I will wear my heart upon my sleeve

For daws to peck at: I am not what I am.

(Othello, I.i.61-5)

The most reliable and detailed register of thought and feeling, as everyday wisdom dictated, was the face. In Ben Jonson's play Cynthia's Revels the foolish courtier Amorphus, who pretends to subtle observation, scorns 'those, which hold the face to be the index of the mind," Lady Macbeth, using the same metaphor, shows herself acutely aware of the eloquence of facial expression, in warning her husband not to give away too much:

Your face, my thane, is as a book, where men

May read strange matters.

(Macbeth, I.v.62-3)

The actor, like the painter, lived 'by making mouthes and faces,' as 
George Chapman puts it, which were expected to reveal an essential truth of character, whether or not words accompanied them. Actors on the stage could be observed and appreciated as are the figures in the 'piece of skillful painting' on the subject of the Trojan war, which Shakespeare describes in his poem The Rape of Lucrece:

In Ajax and Ulysses, $\mathrm{O}$ what art

Of physiognomy might one behold!

The face of either cipher'd either's heart,

Their face their manners most expressly told:

In Ajax' eyes blunt rage and rigor roll'd,

But the mild glance that sly Ulysses lent

Showed deep regard and smiling government.

(1394-1400)

If the face was the cipher of the heart, and therefore the centre of the actor's language of expressive visual signs, the centre of the face in turn lay in the eyes, as the description of Ajax and Ulysses suggests. The communicative power of the eyes, capable of both subtle shades of feeling and forceful, overpowering emotion, was and is sufficiently a matter of commonplace observation as to render detailed commentary superfluous. Thomas Wright's attempts to summarise a few parts of the complex language of 'most speaking looks' soon founder in rather lame stock descriptions. 'This subject is very ample, and would require almost a whole book,' he notes, though it can hardly be regretted that he didn't write it when one judges by what he considered to be its 'chiefe points." The tendency of observers to generalise and to moralise what they see is a plague all too familiar to students of the Renaissance in many areas, but there is enough in Wright's book, particularly in his comments on music, to show that he was open to sensory and aesthetic pleasures in ways more fresh and more sophisticated than his rehearsal of wooden types of behaviour and appearance would suggest. There certainly is no need to assume that actors stopped at the simplified prescriptions of the behaviour thought appropriate to certain characters or situations: only the naive Bottom conceives of his role as a fixed mask to be put on readymade, in which one rages or condoles as required. The subtly expressive language of the eyes, thoroughly and immediately eloquent yet frequently mysterious and elusive, incapable of being reduced easily or concisely to verbal description or analysis, does not conform comfortably with the Renaissance habit of describing looks or behaviour as typi$\mathrm{cal}$ and recognisable.

At the same time, certain types are described precisely in terms of the appearance of their eyes, particularly the only two characters Bottom thinks worthy of his gifts: "a lover, or a tyrant." The behaviour of the 
lover, like the rhetoric of love, is inseparably connected with the eye. A glance through the standard modern concordance to Shakespeare, in which no less than seven full pages are devoted to 'eye' and 'eyes,' yields a host of largely unsurprising adjectives and descriptive phrases, among them 'sweet,' 'charming,' 'bright,' 'pretty, 'fair,' 'heavenly,' and 'dove's' eyes. ${ }^{8}$ Afflicted by the melancholy brought on by unrequited passion, the conventional lover is known by 'a blue eye and sunken,' 9 while rapturous emotion produces 'a fire sparkling in lovers' eyes.' 10 Such pervasive general phrases do not usually tell us a great deal about the work of the actors on stage - in Romeo and Juliet, for example, angry aggression is also 'fire-eyed'11 - all that we can safely infer is that observers were constantly exhorted to look to the eyes as a register of emotional temperature, as it were. In his comedies Shakespeare frequently has great fun with the absurdities of the conventional masks and poses of love, but his satire is tempered by his allowing the lovers to achieve a new validity for the old language, by understanding it from within, and hence convincing an audience of its emotional worth. As far as this process is connected with stage gesture I would say that the conversion from the affected to the real, if I may put it in that way, is marked by an abandonment of the larger signs of conventional love - folded arms, hanging head, humorous sighs, dishevelled clothing - for the concentration of intense emotion in the eyes: the true lover is altogether stiller, less 'fantastical,' than the man or woman in love with love. The actors, involved in the necessary business of suiting the action to the word, are given certain reminders at such important moments, and the audience simultaneously receives an amplification of the significance of what they see. In Love's Labours Lost, a play wittily concerned with the natural predominance of 'the heart's still rhetoric, disclosed with eyes' ${ }^{12}$ over formal reason and book learning, the actor of Navarre must make sure that his performance in the first scene of the second act reasonably matches Boyet's subsequent report of his fascination with the Princess ('Methought all his senses were lock'd in his eye'), ${ }^{13}$ while the disguised Viola in Twelfth Night remembers Olivia's gaze:

She made good view of me; indeed so much

That methought her eyes had lost her tongue,

For she did speak in starts distractedly.

(II.ii.19-21)

The importance of the actor's matching the demands of the text is nowhere more apparent than at the start of II.ii of Romeo and Juliet, where Shakespeare constructs a little dumb show with accompanying commentary, a formal device of contemporary drama which he otherwise 
uses very sparingly. Romeo watches the silent figure of Juliet on the balcony, and makes his own interpretation of her appearance:

She speaks, yet she says nothing; what of that?

Her eye discourses, I will answer it.

The discoursing eye was, I believe, a major part of the actor's stage language, on which Shakespeare made continual demands. The leading actor of his company, Richard Burbage, was remembered in an elegy for his death in 1619 for his 'liuly' acting, a vague enough phrase, but what had impressed itself on the poet's memory was the eloquence of his eyes:

oft have I seene him, leap into the Grave suiting the person, $w^{\text {ch }}$ he seem'd to have of A sadd Lover, with soe true an Eye

that theer I would have sworne, he meant to dye. ${ }^{14}$

The commanding power of the prince or ruler was also conventionally figured in the eye. James I, explaining the importance of speech and action to his son in that book of precepts, Basilikon Doron, repeats the Ciceronian wisdom of 'framing ever your gesture according to your present actions: looking gravely and with a maiestie when yee sit in judgement,' ${ }^{15}$ and so forth. On the stage the formal identity of the prince was signalled by the crown and stage throne, but the personal qualities of the ruler, so important to Shakespeare in the English histories, could more subtly be revealed by the manner in which the actor portrayed the regal countenance, able 'to monarchise ... and kill with looks.'"16 Shakespeare's Richard II, though unable to keep control over his kingdom and subjects, yet retains to his death the natural command of his eye, 'As bright as is the eagle's,' which 'lightens forth / Controlling majesty.'17 The charisma which Bolingbroke evidently commands offstage, on the other hand, receives very little attention through internal reference to his gesture and expression when he is actually present. Claudius, in offering Hamlet 'the cheer and comfort of our eye, ${ }^{, 18}$ is hopefully granting himself the sun-like influence of the benevolent monarch; old Hamlet's picture shows a less congenial ruler, whose eye is made "to threaten and command,' ${ }^{19}$ though as a ghost he appears 'more / In sorrow than in anger.'20 Horatio reports, we should notice, that the ghost's eyes were 'fix'd ... Most constantly'21 upon him in the opening scene of the play.

Probably the safest thing to say about Elizabethan acting is that it is likely to have embraced a range of styles, as the players suited their action to stiff, florid verse or to looser prose that was sometimes very 
close to contemporary slang. When, in the introductory dumb show to the play for the court at Elsinore, the player Queen 'makes passionate action,' 22 as the stage direction tells her to do on discovering the body of her husband, a number of things may have happened at the Globe theatre. There was, for example, a reasonably widely recognised conventional gesture to signify feminine grief, described by the character Lycus in the fourth act of Chapman's comedy The Widow's Tears: 'I never saw such an exstasie of sorrow, since I knew the name of sorrow. Her hands flew up to her head like Furies, hid all her beauties in her discheuel'd hair, and wept as she would turne fountaine. ${ }^{23}$ The actor of the Queen may have done something similar, though if he followed the lead of the head of his company he may have tried a subtler and more deeply impressive action, concentrating the grief in the expression of the face, and leaving it visible to the audience. It is the pale, tearful face of the Player that affects Hamlet above all else, as it was the face of the dead Desdemona that moved the audience of Othello at Oxford in $1610 .{ }^{24}$ Yet it has been maintained that Elizabethan acting was a 'large' style and that it 'apparently eschewed small or over-subtle facial expression.' I quote Daniel Seltzer's account of acting and staging from $A \mathrm{New} \mathrm{Com}$ panion to Shakespeare Studies, published in $1971 .^{25}$ There certainly is evidence to support such a point of view, and the typical reason advanced to account for it is that the public playhouses were large-recent scholarship certainly has confirmed that ${ }^{26}$ - and therefore that the actors' faces were not visible in detail to a good part of the audience. Hence, the argument continues, Elizabethan action typically included large gestures of the hand and arm to amplify the expression of thought or emotion. That the actors used such gestures seems clear enough, but that it was a closely codified language or that it was always used I am inclined to doubt. Well-judged oratorical gestures of the hand could fascinate an audience, but their communicative power, for obvious reasons, was decidedly limited when compared to the range and depth of meaning transmitted by the face. Internal references in Shakespeare's writing confirm this observation: accounts of facial expression abound, while references to manual gesture are few. The fullest description of its effectiveness occurs in the passage on the painting of Troy from which I quoted above:

There pleading might you see grave Nestor stand,

As 'twere encouraging the Greeks to fight,

Making such sober action with his hand,

That it beguil'd attention, charm'd the sight.

(Lucrece, 1401-4) 
Notice that the suggestion of the passage, though the poet is describing the effect of a painting, not of an oration directly, is that oratorical gesture is not a physical equivalent for words or concepts, but a kind of dance which, like the movements of eye and face, signifies in a manner different from that of speech.

There were a limited number of conventional movements or postures involving the hand which signalled particular attitudes or mental states. Grief or tension could be indicated by wringing the hands, unbearable anguish by beating the breast with palm or fist, supplication by holding up joined hands from a kneeling position. To join hands with another character was a gesture appropriate to lovers; to do so could also signify friendship or political alliance. Otherwise there is little evidence in the plays themselves that the hands were used in a manner other than as suitable accompaniment, as continuo, to the sense created by vox and vultus, or that the actor was not free to adapt the abstract, non-specific gesture of hand and arm to the demands of the role as he saw them. Hamlet's famous stricture on 'sawing the air' is not directed against the wooden literalism of rhetorical gesture, as is some contemporary criticism of bookish acting, nor does he prescribe any specific remedy other than a sense of what is fitting: the actor's judgement is to be his own guide in avoiding absurdity. ${ }^{27}$

Both kinds of action, the specific and what I have called the abstract, can be observed in one of the nearest approaches we have to an illustration of Elizabethan actors on the stage, the drawing, of about 1595 and possibly made by Henry Peacham, of characters from Shakespeare's Titus Andronicus (fig. 1); it is, unfortunately, not entirely reliable as evidence of a performance, though it may be drawn from memory of one. The kneeling figure right of centre, Tamora, Queen of the Goths, is in the formal pose of supplication, pleading for the life of her son. Opposite her is Titus himself, spear in his left hand, right hand and arm extended out and down diagonally from the shoulder, weight on the right leg, while the left leg is slightly bent, and to the rear. He may be walking forward, but it is clear that he is speaking, and the ample movement of his right arm is employed, as he himself says in the play, to 'grace' his 'talk. ${ }^{28}$ The drawing catches him in the middle of the movement and interrupts its flow, and it is precisely the point of such non-specific gesture that it provides a visual accompaniment to the flow of speech; the actor is free to stop it or to be indicative where a special emphasis is needed. Such an emphatic gesture is being made by the figure of Aaron, at the right of the sketch: its sense is universal, and needs no gloss.

If manual gestures on the stage provided clarification of facial expression which could not be clearly seen by all the audience, it would be wrong to infer that therefore facial expression was not particularly 
116 / Renaissance and Reformation

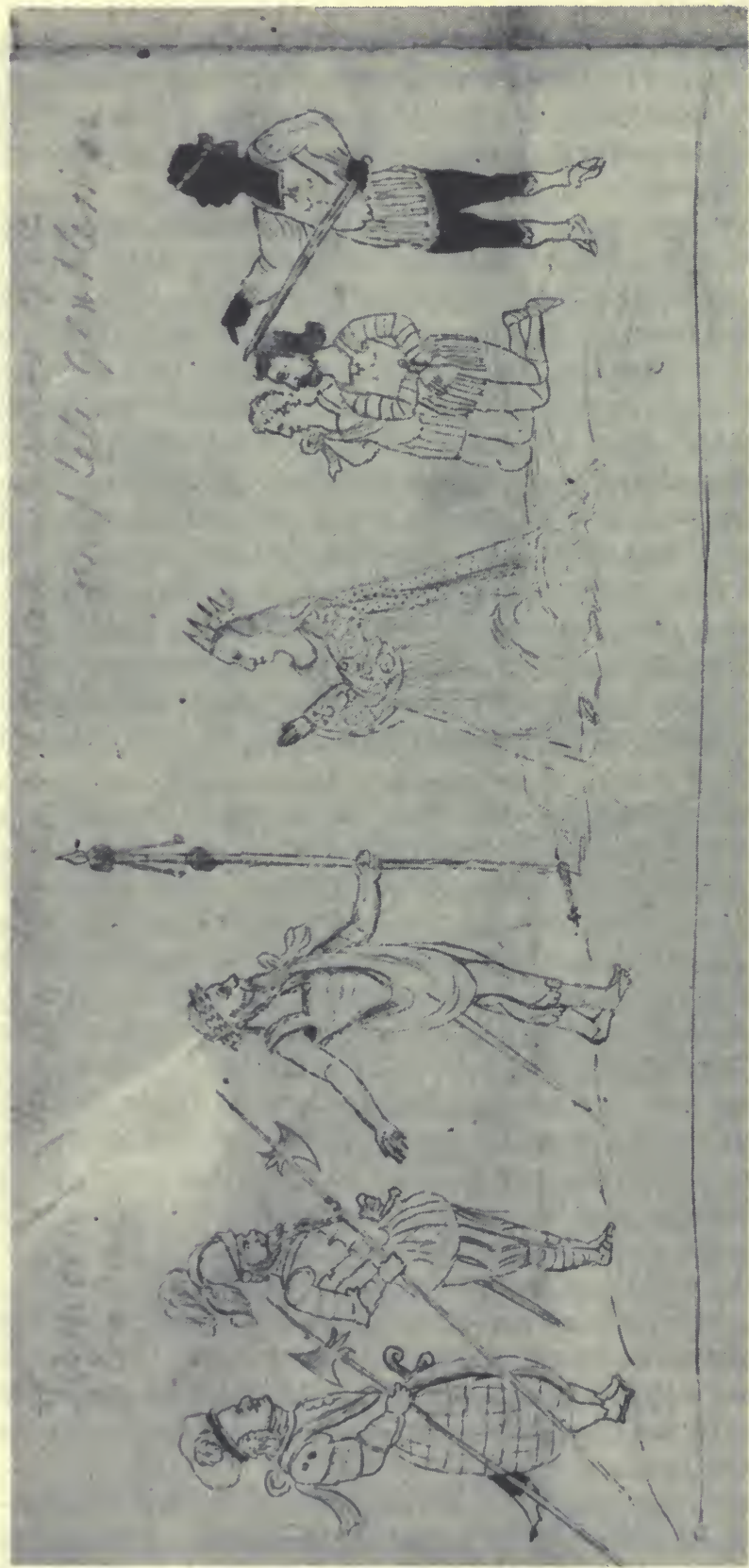

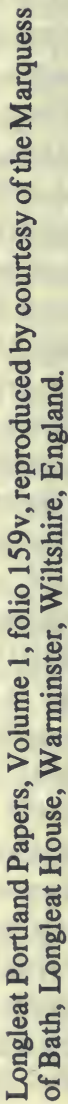


important to the actors: the evidence points entirely in the other direction. If the theatres were large, so were many churches and outdoor preaching places, but preachers certainly were expected, as the manuals of oratory and rhetoric make clear, to use the expressiveness of the whole countenance, as well as gestures of hand and arm, to impress themselves on their auditors. For the actor the face, and especially the eyes, formed the centre of visual communication: the hand was the follower or the agent of what flowed from that centre. The natural hierarchy of the body decreed that this should be so. The eyes, with the ears and tongue, were directly connected to intellectual power, to the heart, and to the soul: the eyes, moreover, both received and transmitted impressions in a way the other organs could not. They were 'the bewrayers and tokentellers of inward conceiptes,' ${ }^{29}$ rivals, it might seem, of the supposedly superior inner organs of thought and feeling. In Sonnet 46, Shakespeare is engaged in a 'mortal war' between his 'eye' and 'heart,' over which best represents the image of the loved one; by the next poem a saner alliance has been formed:

Betwixt mine eye and heart a league is took, And each doth good turns now unto the other.

(Sonnet 47, 1-2)

In so far as the eye represented the commanding intellect, the relationship between it and the hand, representing the agency of the body, was that between will and performance, and necessarily between higher and lower. As outward signs of the soul the eyes could reveal the tension between the conscience and the predominantly sinful body. Thus the actions of eye and hand, of vultus and vita, if we may for the moment limit that third term to movements of the limbs, need not always be in accord, and more complex mental states could be figured by a disjunction or a perversion of the sympathetic relationship between them. The formal meaning of a gesture could be belied by the eyes, as it could by the voice: thus Lear mocks the action of beseeching his daughter for food and shelter, and in the fifth act of Richard II the Duchess of York urges King Henry not to believe the perverse petition of her kneeling husband - he is not acting to the life:

Pleads he in earnest? Look upon his face:

His eyes do drop no tears, his prayers are in jest,

His words come from his mouth, ours from our breast;

He prays but faintly, and would be denied,

We pray with heart and soul, and all beside.

(V.iii.100-4) 
Coriolanus, whose 'lip and eyes' are carefully noted by the tribunes early in the play,${ }^{30}$ abases himself in the gown of humility very stiffly indeed, and subsequently refuses to have anything more to do with politic persuasion,

Lest I surcease to honor my own truth, And by my body's action teach my mind A most inherent baseness.

(Coriolanus, III.ii.121-3)

The play in which Shakespeare exploits most fully the actor's ability to disintegrate the various parts of 'lively action,' to sound discords in place of the expected harmony, is Macbeth. This is a subject, to echo Wright, very ample, and would require almost a whole book, so let me conclude with a few, necessarily compressed observations. Macbeth is a play of spectacle, or of 'show,' to use a word much repeated in the text; it is likely to impress itself strongly on our visual memory. Many of the shows it presents are grotesque, strange, or horrifying, but several of the most memorable are created with the primary medium of the actor's face and body: a demented woman rubs obsessively at her white hands, which she imagines to be covered with blood; a man stares out into the audience in fascinated horror as he sees his vision of the floating dagger, suddenly reaching convulsively out to catch it. The action of eyes and of hands has an entirely central significance in Macbeth, where quite simple gesture has extraordinary resonance. Hands represent power, execution (in a grim double sense), brute strength, fallen Nature; eyes, more ambiguously, since they reveal both impulse and the process of reflection, ambition, resolution, will, conscience, remorse, anguish. Macbeth's perverse sin is to invert the natural hierarchy of body and mind: his hand, he says more than once, is to lead his eye:

The eye wink at the hand; yet let that be

Which the eye fears, when it is done, to see.

(I.iv.52-3)

Strange things I have in head, that will to hand,

Which must be acted ere they may be scann'd.

(III.v.138-9)

Finally, in the fourth act, having significantly obliterated the eyes entirely from the language he uses, so that there is no middle term between desire and performance, and having terribly reduced the word 'heart': 
From this moment

The very firstlings of my heart shall be

The firstlings of my hand.

He succeeds only in part. Though his fame at the beginning of the play is achieved as a man of action, the audience in the theatre apprehends him first and foremost as a contemplative character ('Look how our partner's rapt') ${ }^{31}$ whose inner life races ahead of immediate, tangible surroundings, and is physically revealed in his eyes. We do not, for example, see him engaged in physical violence until the very end of his life, in the battle which he enters almost with a sense of welcome release. The agon of the play is internal conflict far more tense and shocking. Macbeth determines to blind his eyes, meaning his conscience, by the force of his hands, but he ignores the conspiracy of the eyes in the original resolve to murder Duncan, beautifully dramatised in the scene which juxtaposes the 'dagger of the mind' with the 'palpable' knife he clutches in his fist (II.i). The eyes are both allies and opponents of the murdering hand: they first create a seductive invitation to ambition and power, then transform it into a horrifying accusation. A natural impulse of the actor playing these lines is to move his free hand to his face, first tentatively, checking the evidence of what appears to be ('Mine eyes are made the fools o' th' other senses, / Or else worth all the rest.' 44-5), then convulsively, blocking what he wills not to see: 'There's no such thing' (47). Once he has crushed out the vision, whether or not with a literal gesture of the hand, the lines which follow are: 'Now o'er the one half world / Nature seems dead...' (49-50).

His second mistake, following the initial murder, is to give his hands nothing to do, leaving himself at the mercy of the dreams and visions Banquo's ghost, or the show of kings - with which he is less and less able to cope. The actor's performance during the scene of the ghost's appearance (III.v) will express Macbeth's horror through his eyes and face ('Why do you make such faces?' 66), but part of the grim comedy of the scene is contained in the antics of a man who does not know what to do with his hands, caught between guilty, legalistic, self-justification ('Thou canst not say I did it' 49) and a desperate, flailing bravado:

\section{What man dare, I dare.}

Approach thou like the rugged Russian bear,

The arm'd rhinoceros, or th' Hyrcan tiger,

Take any shape but that, and my firm nerves

Shall never tremble. Or be alive again,

And dare me to the desert with thy sword;

If trembling I inhabit then, protest me 
The baby of a girl. Hence, horrible shadow! Unreal mock'ry, hence!

The final cries, I think, invite the actor to echo the gesture of covering the eyes with the hand, crushing out unwanted experience by self-mutilation, as the words echo the earlier lines from the scene of the visionary dagger.

It may be objected that such interpretations are speculative; I certainly do not think that they have any particular authority beyond being based on a clear verbal emphasis within the text itself. The conflicts and divisions between eyes and hands need not consistently have been made physical, but there is one remarkable moment at which Shakespeare insists on a direct connection between words and actions, when the monster Macbeth has made of himself is amazingly embodied in perhaps the most impressive stage gesture the dramatist ever created. In the second scene of act two, Macbeth's hands, red with the blood of the murder of Duncan, rise to his own face to claw out the accusing eyes' white and distended with terror. Such complex power arising from such simple physical elements necessarily depends on context and speech, but it relies otherwise on the usual stage language of Elizabethan players, to quote Wright, the 'motions ... stirring in the eies, hands, [and] bodie.' 32

University of Toronto.

\section{Notes}

1 All Shakespeare quotations are from The Riverside Shakespeare, ed. G.B. Evans et al. (Boston, 1974).

2 Thomas Wright, The Passions of the Minde (London, Second edition, 1604), p. 176.

3 Ibid.

4 II.iii; Ben Jonson, ed. C.H. Herford and P. Simpson, vol. IV (Oxford, 1932), p. 70.

5 Monsieur D'Olive, I.ii.100-1; The Plays of George Chapman. The Comedies, ed. A. Holaday (Urbana, 1970).

6 Wright, p.131.

7 A Midsummer Night's Dream, I.ii.22.

$8 \mathrm{M}$. Spevack, A Complete and Systematic Concordance to the Works of Shakespeare, IX vols.

(Hildesheim, 1968-1980).

9 As You Like It, III.ii.373-4.

10 Romeo and Juliet, I.i.191.

11 Romeo and Juliet, III.i.124.

12 Love's Labours Lost, II.i. 229.

13 Love's Labours Lost, II.i.242.

14 Quoted in A Dictionary of Actors, E. Nungezer (New Haven, 1929; New York, 1971), p. 74. 
15 The Political Works of James I, Ed. by C.H. McIlwain (Cambridge, Mass., 1918; New York, 1965), p.47.

16 Richard II, III.ii.165.

17 Richard II, III.iii.68-70.

18 Hamlet, I.ii.116.

19 Hamlet, III.iv.57.

20 Hamlet, I.ii.231-2.

21 Hamlet, I.ii.233-4.

22 Hamlet, III.ii.135-6.

23 Hamlet, IV.i.34-37; ed. cit., p. 516.

24 See the account cited by M. Rosenberg in "Elizabethan Actors: Men or Marionettes?' PMLA, 69 (1954), 915-27.

25 Ed. K. Muir and S. Schoenbaum (Cambridge), p. 42.

26 See J. Orrell, The Quest for Shakespeare's Globe (Cambridge), 1983).

27 See Hamlet, III.ii.1-45.

28 Titus Andronicus, V.ii.17-8.

29 Lemnius, The Touchstone of Complexions (London, 1581); cited by R.A. Foakes in "The Player's Passion. Some Notes on Elizabethan Psychology and Acting," Essays and Studies, vol. 7, n.s. (1954), 62-77.

30 Coriolanus, I.ii. 255.

31 Macbeth I.iii.142.

32 The Passions of the Minde, p. 179. 